\title{
Sundanese's children naming tradition: A descriptive case study of language maintenance and shift in Bandung
}

\author{
Rudi Suherman \\ Correspondence \\ Email: rudipipit11@gmail.com
}

English Education Program, Universitas Persatuan Islam, Indonesia

Received:

17 November 2020
Revised:

10 February 2021
Accepted:

27 February 2021
Published:

28 February 2021

\begin{abstract}
A name given to someone may represent his ethnic background. Therefore, it is likely used by most people in recognizing where someone comes from. This study is aimed at examining the possible correlation between children's name given by their Sundanese parents with their ethnic background in maintaining the Sundanese language in local region in Bandung, the Capital city of West java. 17 Sundanese family are involved in this descriptive case study. Both parents, representing by 17 fathers and 17 mothers, originally come from different region in west java province and have resided in Bandung for more than a decade. The data, embracing the characteristic of survey, are gained from a set of questionnaires and semi -structured interview consisting of questions related to family's background, the name given, as well as the reason that drives them giving the names. This study has revealed the current trend on naming tradition in Bandung in which there is a shift from Sundanese, to other language particularly Arabic. This may be happened because most of the participants in this study are Muslims. Hence, Arabic as the language of Islam predominantly influence the naming tradition in Sundanese family.
\end{abstract}

Keywords: Sundanese parents; naming tradition; language maintenance; language shift.

\section{INTRODUCTION}

It has been a common knowledge that Indonesia is one of the largest archipelagic country in the World. It has more than 17000 islands ranging from the north to the south (Martha, 2017). Besides, the country stretches out from Sabang to West Papua which is approximately almost close to 2900 kilometers (Bakri et al., 2017; Ginting, 2020). This situation leads Indonesian to be multicultural countries in terms of costume, ethic and language. Indonesian cultural are massively diverse. Among 34 provinces in Indonesia, there is always a distinctive culture that differ to one and another. The uniqueness of each culture can be obviously distinguished through its dress, food, costumes, music and name. It has been remarked that the latter, as well as other cultural products such as language and festival are the tangible and intangible emblem, a tool that can serve in identifying a person's background 
Suherman, R. (2021). Sundanese's children naming tradition: A descriptive case study of language maintenance and shift in Bandung. EduLite: Journal of English Education, Literature, and Culture, 6 (1), 189197. http://dx.doi.org/10.30659/e.6.1.189-197

(Aribowo \& Herawati, 2016). Therefore, Proper name or name which literary given by the parents to their children may become the most practical clue of someone's identity (Kirkness, 2000).

Name possessed by someone has considerably been essential aspect in recognizing oneself when he/she socially engages in community. Scientifically, the study of naming system is discussed in onomastic study (Bright, 2003; Tóth, 2014). In addition to this, the contribution of onomastic study can be utilized in comprehending how a name works. This approach can also be used to describe the social, historical as well as linguistics aspect of one's identity (Aribowo \& Herawati, 2016). Therefore, the components some crucial backgrounds under pinning its construction can relatively be found easily (Kosasih, 2010).

The language usage in every region in Indonesia may vary to one and another. Each region relatively has its own local language which accounts for its identity. Therefore, Indonesia is widely considered as a multilingual country due to its language diversity. It has been identified that there are at least 467 Austronesian language are spoken in Indonesia ranging from Sabang to Merauke as the western and northern tip of Indonesia (Indrayani, 2011). As a multilingual nation, there are eight major languages categories that widely spoken, one of which is Sundanese. It is the mother tongue of an ethnic whom live in the western part of the java island called Sundanese people.

In the context of daily life, naming is usually used as the reference terms that normally use as personal distinctive feature to differ one person to another (Widodo, 2015). It also represents the psychological condition of a certain community. If someone doesn't have a name, it is highly unlikely for the member of community of people who interact with him or her to identify where he/ she comes from, what language he/she speaks etc. This may apply to Sundanese as one of the largest ethnics in Indonesia (Musgrave \& Hajek, 2010). for Sundanese people, naming system or naming tradition is important, meaningful and containing an inner soul attached along his/her life in the world (Kosasih, 2010). Furthermore, it may carry the mysterious elements, so that process of giving name may through a series of traditional ceremony call "bubur bereum bubur bodas" which is translated as "red porridge and white porridge". This ceremony also acts as an expression of gratitude in welcome a new family member (Anshori, 2018).

However, according to previous research such us conducted by Riyanto (2016; Wagiati \& Zein, 2018) as one of the largest ethnic and the owner of the second largest language in Indonesia, Sundanese people, in the present day, tend to neglect their mother language on daily basis, including in giving name to their children. Sundanese people have a tendency to have a negative perception toward their mother language (Indrayani, 2011; Riyanto, 2016; Wagiati \& Zein, 2018).

The name which is given to someone may represent his ethnic background, cultural reason and hope or pray of their parents. Therefore, it often can be used by most people in recognizing where someone comes from. This study is aimed examining the possible correlation between children's name given by Sundanese parents to their children with their ethnic background in maintaining the Sundanese language in local region in 
Bandung, the Capital city of West java. In addition to this, this article is expected to unfold the preferences and the reason that drives the Sundanese parents who currently live in Bandung in giving the name to their children and how they value Sundanese as their mother language in the current contexts.

\section{METHOD}

This study is aimed at capturing a contextualized picture of a particular phenomenon where in this study the emphasis is simply on gaining an understanding of Sundanese naming tradition in the present day. Thus, descriptive case study is employed embracing characteristics of survey in term of the instrument which serves as an appropriate way to generate data from large group of people or entities (Creswell, 2007; Heigham \& Croker, 2009; Fraenkel, 2017; Lewis, 2015). In gathering the data, set of questionnaires followed by semi-structured interview were distributed and were applied to 17 different Sundanese family. The parents, representing by 17 fathers and 17 mothers, originally come from different regions in West Java province such as Tasikmalaya, Garut, Sukabumi, Padalarang, and have been residing in Bandung for more than a decade. The data were gained from questionnaire and semi - structured interview relate to family's background, the name given, as well as the historical reason underpinning the given name or possessed by their children. The questionnaires were not directly conducted to the parents, yet the template was given to their children who studied in local teacher training college in Bandung in which the researcher works at.

Each of the children who were also the researcher's students were given the set of questionnaires as part of the survey in regard with aim of this study. They were also told that this study is on the voluntary basis, meaning, they were allowed not to participate or withdraw from the survey being conducted. They were asked to interview their parents at their convenience. They were given two weeks to accomplish or fill in the survey since the survey sheet given to them.

The participants were asked to filled out the questionnaires consisting of 6 questions, and 3 of the participants were invited to join the interview. The interview served as a way to explores some data findings that need further explanation or clarifications. It was conducted either offline or online through phone calls depending on their willingness and availability. It lasted around $15-20$ minutes per session. The Interviews was conducted in participants' first language. The result from the questionnaire were analyzed quantitatively which is displayed in percentages (\%), and the interviews result were analyzed qualitatively. Both results, questionnaire and interviews, were then analyzed as such in order to gain rich and robust finding (Creswell, 2007; Creswell, 2013; Ubaidillah, 2018).

\section{RESULTS AND DISCUSSION}

There were 55 different names that has been successfully collected from the distributed survey. They were collected from 17 families. These names were then classified into several categories based on its language references used in each name. Based on the finding, there were at least three major languages that exhibit in this study; Sundanese, Arabic, and various combination of 
Suherman, R. (2021). Sundanese's children naming tradition: A descriptive case study of language maintenance and shift in Bandung. EduLite: Journal of English Education, Literature, and Culture, 6 (1), 189197. http://dx.doi.org/10.30659/e.6.1.189-197

language elements such as Arabic - Sundanese, and Arabic - Javanese. There was also one name derives from Bahasa Indonesia. The researcher also presented the name that own by the parents in different table. It aims to see whether or not there is a shift tendency and positive correlation between the parents' name and the name which given to their children. The data were presented in Table 1.

Table 1 . The percentage of children name based on its language origin

\begin{tabular}{ccc}
\hline Language & Number & Percentages \\
\hline Sundanese & 4 & $7.27 \%$ \\
\hline Arabic & 25 & $45.45 \%$ \\
\hline Combination & 25 & $45.45 \%$ \\
\hline Indonesian & 1 & $1.81 \%$ \\
\hline
\end{tabular}

Table 1 above shows the percentages distribution of children name based on its language origin. The total number name that can be collected are 55 names. As it can be seen, the percentages of children who has Arabic name is six time bigger (45.45\%) than Sundanese name $(7.27 \%)$. Its percentages are the same as the percentages of the children whose name contains various combination of language elements, it takes up to $45.45 \%$.

There are only 4 names of children who own Sundanese language on their names, and there is only one child whose name is taken from Indonesian. This percentages data indicates the shift and switch of children naming tradition from their language background to certain another language, in this case, Arabic, as the consequence of the value they believe that Arabic is ideologically related to their religion, Islam. Therefore, religion is considered an important aspect in the life of most Indonesian (Muslim, 2015).

To view the correlation between the name owned by the children, and the name owned by parents, the researcher displays the percentages of parents' name based on its language origin. Then percentage between them are compared. The table is presented in Table 2 .

Table 2. the percentage of parents' name based on its language origin

\begin{tabular}{ccc}
\hline Language & Number & Percentages \\
\hline Sundanese & 16 & $51.61 \%$ \\
\hline Arabic & 7 & $22.58 \%$ \\
\hline Javanese & 3 & $9.68 \%$ \\
\hline Combination & 5 & $16.13 \%$ \\
\hline
\end{tabular}

The number of the name parents that are successfully compiled are 31 names as it taken from 17 parents. Ideally, it is supposed to be 34 as it represented by 17 mothers and 17 fathers. However, only 31 names that were successfully collected. This happened due to several reasons such as the parents demand not to get their name listed in this study, there is also a single parent, mother or father, who prefers to not list or write his or her deceased partners. 
It is obvious that the name owned by parents are majorly taken from Sundanese as their mother language such as Ujang, Asep, Kokom or Asmanah. However, the interference of foreign language, in this case, Arabic, cannot be put aside. It takes up to $22.58 \%$ of the total represented by seven different names such as Ahmad Buchori, or Ummi Kulsum. In addition, the combination name come into the third place in which Sundanese - Arabic as well as Sundanese - Indonesian such as Asep Ridwan for the former, and Edi Purnomono are quite predominantly on this category. The least category is from Javanese language which consists of three names (9.68\%). This may happen as one the parents, mother or father comes from Javanese who married with Sundanese.

Based on the data above, it can be drawn a conclusion that Sundanese parents tend to name their children with name taken other than from Sundanese (Muslim, 2015). Arabic becomes the predominately reasonable language option as all of the parents are Moslems. This finding is in line with It previous studies in which The Javanese people named their children using Arabic as way of actualizing self-identify as a Muslim and this tendency has highlighted their identity as part of Moslems than the Javanese. (Aribowo \& Herawati, 2016; Journal \& Studies, 2017; Widodo, 2015). This finding was also supported by the interview results that the Arabic language was used and entitled to their children names as the distinctive features compared to other religious belief. This may also indicate that as the implementation or Islamic deed in which giving a good name may be categorized as a legacy from the Islamic prophet and religious practice (Ubaidillah, 2012).

Parents 'background may also determine in naming system that given to their children. These are included parents ethnic background, their name, and level of education they acquired. Seventeen families, represented by seventeen husbands and seventeen wives takes part in this study. Fourteen parents are Sundanese couple the other three couples Sundanese who married with other Indonesian ethnic other than Sundanese. Their names are mostly from Sundanese language such as Dede,Yulianti,Nenah, Rosanah Asep, Wawan, and Euis. Their education background also varies ranging from elementary school degree to bachelor degree.

Most of the parents give the name to their children based on several reasons. One of the dominant reasons was due to the hope given to them. Such as Asep Mulyadi which was taken from Sundanese, Asep as the colloquial name of Kasep meaning "handsome" in Sundanese, and Mulyadi, meaning "honour" in Javanese. The parents as it was stated from the questionnaire and interview, hoped that later his son was able to be become a handsome man who deserved to gain or receive the honorary his life socially and economically. This tendency was also found in Javanese society who possess a virtue "asma kinarya japa". According to Aribowo \& Herawati (2016), " this expression means 'name was created from a prayer'. In the other word, in the creation of a name, there is a hope and prayer from parent to their children. Therefore, names often have a spiritual meaning that leads to a parent's request for the next generation" (p.122) Another reason is in accordance with the time when the children were born such as Ali Nur mahgribi in which mahgrib is an Arabic time marker referring to the time to prayer at night. According to his parents, Ali was born when maghrib prayer 
Suherman, R. (2021). Sundanese's children naming tradition: A descriptive case study of language maintenance and shift in Bandung. EduLite: Journal of English Education, Literature, and Culture, 6 (1), 189197. http://dx.doi.org/10.30659/e.6.1.189-197

came. Second example Laila Nur Fadhilah. Laila is taken from Arabic language Lail meaning at night or Mariam Destiar who was born in December. Since she was a baby girl, destiar was attained. Her parents argued that destiar was believed as reference to feminine marker of December, the $12^{\text {th }}$ month in solar year.

There was also a unique reason of naming given by the parents to their children. Parents tend to give the name to their parents due to personal or family reason which may not be able to be predicted or guessed, idiosyncratic feature, by other if it was not asked directly to them. For example, Della Utami Pratiwi, Della is not taken from single word yet it is the abbreviation from Dede, the Father's, and Yulia, the Mother's. Similar case also happened to Ayu safitri Gina, at glance, Ayu may seem to be taken from Javanese word meaning "beautiful". However, the parents argued that Ayu was the combination of two different name Agus, and Yuyu. The grand parents of the children. It was given as a way of honor to her ancestor and as it was clearly stated that the parents argued that they hoped their child would always remember their ancestor, and it was also a symbol of courtesy as well as commemoration for them.

Some names were taken from their distant family name, such Nur faida regar in which regar is bataknese surname specifically attained to a daughter as opposed to siregar for son. The parents considered this approach was purposively to have their children remember where they were originally from. Whereas, Other persistently remained with Sundanese name by having repeated sound such as [wi] as in wiwin winardi or [ya] as in Yayat Ruhiyat. These features were commonly believed as a Sundanese onomastics trait.

Another finding from the semi structure-interview that worth discussing was related to perception of few parents who argued that naming was not relatively in line with the language existence. For them, the only way to maintain the existence of their mother language was by teaching children the language directly and practiced it on daily basis. Others even considered Sundanese name was not compatible with their children who were born in this era. They thought that Sundanese name seems too sacred to be attained to children whereas others called it relatively old-fashioned and quite incompatible. Hence, the children, according to them, deserved to have modern names which might more representative for millennial generation.

\section{CONCLUSION}

This article may not represent the actual condition of Sundanese naming tradition that correlates to Sundanese in maintaining their mother language at the present day. Thus, the generalization is too early to be drawn. Nevertheless, it is likely able to depict the current trend on naming tradition in Bandung in which there is a convergently shift from Sundanese language to other languages particularly Arabic. This may be happened because most of the participants in this study are Muslim. Hence, Arabic which is believed as the language of Islam and is considered higher virtue predominantly influence the naming tradition in Sundanese family in this study.

It is advisable for future researchers who are interested in the similar research area to employ wider sample of population from all areas of Bandung and other west java regencies/cities in which Sundanese resides and to utilize probability sampling. It aims to provide more robust, comprehensive and 
EduLite Journal of English Education, Literature, and Culture Vol. 6, No. 1, February 2021, pp. 189-197

reliable findings in which generalization can be drawn. In addition to this, the participants from different religion backgrounds should be considerably taken into account in the future studies, as their onomastics may not be in line with the present study.

\section{ACKNOWLEDGEMENTS}

I would like to thank Universitas Persatuan Islam which has funded the publication of this research. The sincere thankful is also address to all Universitas Persatuan Islam students who have been willing to participate in this study. 
Suherman, R. (2021). Sundanese's children naming tradition: A descriptive case study of language maintenance and shift in Bandung. EduLite: Journal of English Education, Literature, and Culture, 6 (1), 189197. http://dx.doi.org/10.30659/e.6.1.189-197

\section{REFERENCES}

Anshori, D. S. (2018). The construction of Sundanese culture in the news discourse published by local mass media of West Java. Lingua Cultura, 12(1), 31. https://doi.org/10.21512/lc.v12i1.3370.

Aribowo, E. K., \& Herawati, N. (2016). Trends in naming system on Javanese society: A shift from Javanese to Arabic. Lingua Cultura, 10(2), 117. https://doi.org/10.21512/lc.v10i2.1730.

Bakri, B., Rustiadi, E., Fauzi, A., \& Adiwibowo, S. (2017). Sensitivity indicators analysis and regional sustainable development status in Indonesia. Jurnal Bina Praja, 9(2), 265-280. https://doi.org/10.21787/jbp.09.2017.265-280.

Bright, W. (2003). What is a name? Reflections on onomastics. Language and Linguistics, February, 22. https://doi.org/2003-0-004-004-000059-1.

Creswell, J. W. (2007). Creswell, J.W. 2007. Qualitative inquiry \& research design $\sim$ Choosing among five approaches , 2nd edition.pdf (2nd edition). Sage Publication, Inc.

Creswell, J. W. (2013). Data analysis workshop. Research Design Qualitative Quantitative and Mixed Methods Approaches, 1(9), 270. https://doi.org/10.1017/CBO9781107415324.004.

Fraenkel, J. R., Wallen, N. E., \& Hyun, H. H. (2017). How to design and evaluate research in education (Vol. 91). McGraw-hill.

Ginting, I. G. K. (2020). The maintenance of Cakap Karo in Kelurahan Sempakata Medan. Linguistic, English Education and Art (LEEA) Journal, 3(2), 476-485. https://doi.org/10.31539/leea.v3i2.1317.

Heigham, J., \& Croker, R. A. (2009). Qualitative research in applied linguistics: A Practical introduction, 7 (2). Palgrave Macmillan.

Indrayani, L. M. (2011). Language vitality: A case on Sundanese language as a surviving indigenous language. International Seminar "Language Maintenance and Shift," 31-35.

Journal, I., \& Studies, H. (2017). IJHS, e-ISSN 2597-4718, p-IS. 1(1), 63-70.

Kirkness, V. (2000). The preservation and use of our languages: Respecting the natural order of the creator. Indigenous Languages Across the Community. Proceedings of the Annual Conference on Stablizing Indigenous Languages (7th, Toronto, Ontario, Canada, May 11-14, 2000), 7, 17-23. http://jan.ucc.nau.edu/ jar/ILAC/ILAC_2.pdf.

Kosasih, D. (2010). Kosmologi sistem nama diri (antroponim) masyarakat Sunda dalam konstelasi perubahan struktur sosial budaya. Seminar Internasional "Hari Bahasa Ibu," 1974, 1-7. http://file.upi.edu/Direktori/FPBS/JUR._PEND._BAHASA_DAERAH/19630726 1990011-DEDE_KOSASIH/PDF/Makalah/Kosmologi_Nama_Diri.pdf.

Lewis, S. (2015). Qualitative inquiry and research design: Choosing among five approaches. Health Promotion Practice, 16 (4). https://doi.org/10.1177/1524839915580941.

Martha, S. (2017). The analysis of geospatial information for validating some numbers of islands in Indonesia. Indonesian Journal of Geography, 49(2), 204-211. https://doi.org/10.22146/ijg.12792.

Musgrave, S., \& Hajek, J. (2010). Sudanese languages in Melbourne: Linguistic 
EduLite Journal of English Education, Literature, and Culture Vol. 6, No. 1, February 2021, pp. 189-197

E-ISSN: 2528-4479, P-ISSN: 2477-5304

http://jurnal.unissula.ac.id/index.php/edulite DOI: http://dx.doi.org/10.30659/e.6.1.189-197

demography and language maintenance. 2009 Conference of the Australian Linguistic Society.

Muslim, A. B. (2015). Sundanese language survival among Indonesian diaspora families in Melbourne, Australia. International Journal of Education, 8(2), 89102. https://doi.org/10.17509/ije.v8i2.5316.

Riyanto, S. (2016). Pemertahanan bahasa Sunda oleh mahasiswa (language maintenance by students). Metalingua, 14(2), 243-252.

Tóth, L. (2014). Theory and methodology in literary onomastics proper names in István Szilágyi's novels (in particular in Hollóidö/ Time of ravens) Pázmány Péter Catholic University, Piliscsaba.

Ubaidillah, M. F. (2018). The pedagogy of English as an international language: Indonesian pre-service teachers' beliefs. Journal of Asia TEFL, 15(4), 1186-1194. https://doi.org/10.18823/asiatefl.2018.15.4.23.1186.

Ubaidillah, U. (2012). Interferensi penggunaan nama diri berbahasa Arab di Indonesia (Sebuah kajian sosiolinguistik). Adabiyyāt: Jurnal Bahasa Dan Sastra, 1O(1), 1. https://doi.org/10.14421/ajbs.2011.10101.

Wagiati, N., \& Zein, D. (2018). Pemertahanan bahasa Sunda sebagai alat komunikasi oleh penutur Sunda di kompleks perumahan di Kabupaten Bandung. Suar Betang, 12(1), 27. https://doi.org/10.26499/surbet.v12i1.14.

Widodo, S. T. (2015). The linguistic characteristics of Javanese names a case study in Surakarta Central Java. Asian Journal of Social Sciences \& Humanities, 2(2), 156-163. luna.co.jp/AJSSHPDFs/Vol.2(2)/AJSSH2013(2.2-17).pdf.

Widodo, S. T. (2015). Personal names as an inter-ethnic model of acculturation in Indonesia. Asian Journal of Social Sciences \& Humanities, 4(1), 126-133. http://www.ajssh.leena-luna.co.jp/AJSSHPDFs/Vol.4(1)/AJSSH2015(4.114).pdf\%0Ahttp://ci.nii.ac.jp/naid/40020412996\%0Ahttps://lens.org/140-334817-437-044.

Conflict of Interest Statement: The authors declare that the research was conducted in the absence of any commercial or financial relationships that could be construed as a potential conflict of interest.

Copyright (c) 2021 Suherman. This is an open-access article distributed under the terms of the Creative Commons Attribution License (CC BY). The use, distribution or reproduction in other forums is permitted, provided the original author(s) and the copyright owner(s) are credited and that the original publication in this journal is cited, in accordance with accepted academic practice. No use, distribution or reproduction is permitted which does not comply with these terms. 